\title{
Marcadores genéticos de infecção e suscetibilidade a doenças em patologia diagnóstica e investigativa
}

Neste volume do JBP-ML estamos tendo a oportunidade de apresentar uma série de artigos que refletem a crescente ampliação da interface entre a patologia (diagnóstica e investigativa) e a biologia molecular. Nesses artigos a biologia molecular aparece como ferramenta para a pesquisa de mecanismos de suscetibilidade a doenças ${ }^{(1,3,6)}$ e para a identificação de agentes patológicos na rotina diagnóstica(2). Neste fascículo temos dois artigos com focos nessas duas diferentes áreas de aplicação: um deles, intitulado "Associação do polimorfismo do gene da superóxido dismutase dependente de manganês (Ala-9Val) em homens e mulheres com câncer de mama", examina a associação entre o polimorfismo do gene da superóxido dismutase dependente de manganês (MnSOD) e o câncer de mama. O estudo examina 470 indivíduos, cem com câncer de mama. A novidade é que 164 deles são do sexo masculino, 11 com câncer de mama. Apesar da baixa freqüência do câncer de mama em homens, o que implica dificuldades experimentais, a associação dessa condição com história familiar positiva e, possivelmente, com a expressão de genes como BRCA2, AR, entre outros (revisto por Weiss et al. ${ }^{(7)}$ ), aumenta o interesse de estudos como esse. $O$ estudo mostra maior risco de ocorrência de câncer de mama em indivíduos com o genótipo AA em relação aos com os genótipos AV e $W$ da MnSOD. Os autores são cuidadosos em suas conclusões, ante as limitações do tamanho da amostra. Apenas um entre os 11 pacientes do sexo masculino com câncer de mama apresentava o genótipo AA, resultando no aumento do risco da doença. Essa limitação constitui, por outro lado, elemento de interesse do trabalho: pela própria agregação de 11 casos, e, ainda, por colocar em perspectiva a necessidade (e possibilidade) de estudos em rede sobre uma enfermidade com crescente incidência.

O outro artigo, "Avaliação do protocolo PCR4 de Marchetti em tecidos parafinizados para o diagnóstico da tuberculose cutânea e ganglionar", utiliza uma técnica de PCR (PCR4 proposta por Marchetti et al.(4)) para o diagnóstico de tuberculose ganglionar e cutânea a partir de tecidos parafinizados. É desnecessário que nos alonguemos na ênfase sobre a importância que tem o desenvolvimento de técnicas para detecção de microorganismos em tecidos incluídos em parafina para a patologia diagnóstica e investigativa, especialmente com interesse epidemiológico e de saúde pública. Esse estudo realça elementos da complexidade na aplicação do teste, oriundos de requerimentos de ajustes técnicos para material parafinado e para interpretação dos resultados, levando-se em conta a flora microbiológica local. Alguns desses problemas têm sido confrontados por outros autores ${ }^{(3,5)}$. A pesquisa de protocolos adequados ${ }^{(6)}$ e a introdução de técnicas avançadas de seleção de espécimes ${ }^{(3)}$ surgem como empreendimentos promissores para o desenvolvimento tecnológico nessa área.

Washington L. C. dos Santos Editor da área de Patologia do JBPML

\section{Referências}

I. BICA, C.G. et al. Associação do polimorfismo do gene da superóxido dismutase dependente de manganês (Ala-9Val) em homens e mulheres com câncer de mama.J Bras Patol Med Lab, v. 43, n. 3, 2007.

2. FUJIMOTO, L. B. M. et al. Avaliação do protocolo PCR4 de Marchetti em tecidos parafinizados para o diagnóstico da tuberculose cutânea e ganglionar.J Bras Patol Med Lab, v. 43, n. 3, 2007.

3. IHLASEH, S. M. et al. Laser-capture microdissection forTP53 gene analysis in paraffin-embedded tissues.J Bras Patol Med Lab, v. 43, n. I, p. 6I-7, 2007.

4. MARCHETTI, G. et al. Evaluation of PCR in detection of Mycobacterium tuberculosis from formalin-fixed, paraffin-embedded tissue: comparison of four amplification assays.J Clin Microbiol, v. 36, n. 6, p. 15।2-7, 1998.

5. SHARMA, S. et al. Polymerase chain reaction (PCR) amplification of IS6 110 sequences to detect Mycobacterium tuberculosis complex from fromalin-fixed paraffin-embedded tissues of deer (Axis axis). Vet Res Commun, v. 31, p. 17-21, 2007.

6. SIMONATO, L. A. et al. Avaliação de dois métodos de extração de DNA de material parafinado para amplificação em PCR.J Bras Patol Med Lab, v. 43, n. 2, p. I21-7, 2007.

7.WEISS, J. R. et al. Epidemiology of male breast cancer. Cancer Epidemiol. Biomarkers Prev, v. I4, n. I, p. 20-6, 2005. 